\title{
Managing Heritage Conservation Projects in Relation with Quantity Surveying Profession: The Case of Malaysia
}

\author{
Umi Kalsum Zolkafli*, Norhanim Zakaria', Siti Nor Azniza Ahmad Sekak², Ismail \\ Rahmat $^{2}$ \\ ${ }^{1}$ Centre for Building, Construction \& Tropical Architecture (BuCTA), Faculty of Built \\ Environment, University of Malaya, 50603 Kuala Lumpur, Malaysia \\ ${ }^{2}$ Faculty of Architecture, Planning and Surveying University Technology of Mara, 40450 Shah \\ Alam, Malaysia \\ *umi@um.edu.my
}

\begin{abstract}
Heritage buildings are deteriorating due to time, lack of care, high maintenance cost and lack of comprehensive guidelines and understanding on the management practices. Conservation is the only process that can protect heritage buildings from deterioration. Integrated teams of highly qualified professionals have to be involved in conservation of heritage buildings. As one of the main players in heritage conservation projects, quantity surveyors should develop an in-depth knowledge of heritage buildings, conservation process, specifications and requirements by local and international authority. Therefore, the aim of this paper is to establish relationship of heritage conservation and quantity surveyor competency. This aim is achieved through the following objectives; to identify the features of heritage buildings, to identify the competency of quantity surveyors in heritage building conservation projects and to establish relationships between heritage conservation projects and quantity surveyors' competency. Quantitative method was chosen for this study. The respondents were from the quantity surveyors who are registered with Board of Surveyors Malaysia and has experienced in building conservation project. SPSS (Descriptive Statistic) and PLS were used to analyze the data. Result showed that there is strong relationship between features of heritage building and quantity surveyors' competency.
\end{abstract}

Keywords: Heritage Building, Features, Conservation, Quantity Surveyor, and Competency

\section{INTRODUCTION}

Heritage buildings are deteriorate due to time, lack of care, high maintenance cost, lack of comprehensive guidelines and lack of understanding the management practices (Forsyth, 2007; Idrus, Khamidi, \& Sodangi, 2010). Conservation is the only process that can protect heritage buildings from deterioration. Conservation is defined as the necessary actions taken to prevent deterioration by adopting several approaches that extend the life and basic functions of heritage buildings (Idrus et al., 2010). Conservation process involves judgment guided by professional ethics and public policy (Drury, 2011). Research by Hegazy (2014) shows that, an integrated team of highly qualified professionals have to be involved in conservation of heritage buildings.

Conservation of heritage buildings is a very complex and unique process (Lee \& Lim, 2010; Said, Akshah, \& Ismail, 2013). It contain more technical and economic uncertainty (Reyers \& Mansfield, 2001). When working on conservation of heritage building, the professionals may, with the best will in the world, not know for certain what may be found, once work had started (Beckman \& Bowles, 2004). Kamal, Wahab, \& Ahmad, (2008); Mohamed, Ahmad, \& Ismail, (2002); Siti Nor Fatimah Zuraidi, Zainal Abidin Akasah, (2011) found that, there are still lack of technical knowledge and training among the professionals who involved in conservation of heritage buildings.

Beckman \& Bowles (2004) further added that conventional professional especially architects, engineers and quantity surveyors provides little or no guidance on the conservation and preservation of heritage buildings. According to Lee \& Lim (2010), quantity surveyors should develop a comprehensive knowledge on heritage conservation especially on the techniques, requirements, guidelines, heritage documentation and technical specifications. 
They further added that quantity surveyor tends to overlook the highly specialized works in conservation works and this resulted to the poorly prepared documents that have caused confusions, cost overruns, extension of time, low quality of workmanship and creates contractual disputes during post contract stages. Quantity surveyors must be competent in delivery their services in conservation of heritage buildings.

Nkado \& Meyer (2001), highlights that competence can be described as an action, behavior or outcomes which a person should be able to demonstrate, or the ability to transfer skills and knowledge to new situation within a given occupational area. Whereas PMI 2002 as cited in Dada \& Jagboro (2012) define competence as a cluster of related knowledge, attitudes, skills, and other personal characteristics that affects a major part of one's job, correlates with performance on the job, can be measured against well accepted standards, can be improved via training and development and can be broken down into dimensions of competencies.

Therefore, the aim of this paper is to establish relationship of heritage conservation and quantity surveyors' competency. This aim is achieved through the following objectives; to identify the features of heritage building, to identify the competency of quantity surveyors in building conservation projects and to establish relationships between heritage conservation projects and quantity surveyors' competency.

\section{HERITAGE CONSERVATION}

It has long been stated that conservation is a multi-disciplinary process (Hegazy, 2014). He further added that, the care, protection, conservation and management of heritage buildings and sites involve a wide range of professions from architects, surveyors and archaeologists to historians, engineers, town planners, landscapes architects, as well as management professionals. Each of these disciplines not only makes a contribution to the field of conservation, but also incorporates some aspect into the knowledge base of their own professional organization (Orbaşli \& Whitbourn, 2002). Lee \& Lim (2010) highlighted that; the delivery of quantity surveyors services requires a strong understanding about intricacies of work related to different professionals in conservation of heritage buildings. Stenning \& Evan (2007) indicates that, there are substantial risks of unknown and unforeseen circumstances in conservation works that can easily compromise an initial cost estimate and adversely affect the final cost prepared by quantity surveyors. Strategic decisions about budgets, overall programs and the selection of the contractor inevitably often have to be made before all of the details of the existing building are known (Beckman \& Bowles, 2004). Drury (2011), further added that practicing conservation must be based on an understanding of the heritage values attached to a building or structure, how they are represented in its fabric and the effects on them of different approaches to conserve. Letellier (2007) highlights that; concentration must be made on the physical nature of heritage buildings and on the values conveyed by its structure and intangible aspect. Therefore, in order to deliver quantity surveyors services efficiently, it is crucial to understand why it is important to have a competent quantity surveyor in the area of heritage conservation.

\subsection{Nature of Heritage Conservation}

Complexity and uncertainty are inherent in all construction, no matter what the size of the project (Rahmat, Nordin, \& Ali, 2005). Conservation is increasingly recognized as a complex process, playing an active, and at times decisive, role in the life of an object, building and monument (Pye \& Sully, 2007). Documentation of important historical places allows appreciation for the overall significance and importance of a place in the sense that they provide meaning, understanding, definition, and recognition of cultural significance and values, which is the ultimate aim of conservation (Nur Farhana Azmi, Faizah Ahmad \& Azlan Shah Ali, 2015). Building conservation works involved highly technical activities (Reyers \& Mansfield, 2001). Hegazy, (2014) added that complexity in conservation project is embedded in interdisciplinary nature of conservation policy, work and planning which include a whole team of professional. Complexity arises from the varied nature (through space) of conservation values, threats to conservation values, heritage values and recreational values (Jacobson, Carter, Hockings, \& Kelman, 2011) In the last decade, conservation professionals have responded, engaging in their own exploration of the subjective, contingent and historically situated nature of conservation, but at the same time highlighting the complex range of processes involved (Jones \& Yarrow, 2013). Conservation projects by their nature often involve work that cannot be accurately predetermine in terms of specification (Harun, 
2011; Lee \& Lim, 2010; Mansfield, J., \& Reyers, 2000). Therefore, a competent quantity surveyor must understand clearly the difference of complexity of heritage conservation and new works. Conservation works need an in-depth knowledge of heritage building, the requirements of law and guidelines, the special techniques used and the technical specification.

Malaysia is a member of UNESCO's Convention concerning the protection of the World Cultural and Natural Heritage since 1998. In 7 July 2008, Malacca Historical City and Inner City of George Town has been declare and listed in UNESCO World Heritage List as World Heritage Sites. UNESCO assessed three outstanding universal values (OUVs) out of ten, which highlights to the world a rare example of multiculturalism heritage that is both tangible and intangible and also the unique meeting of various cultures at the historic ports cities of Melaka and George Town. As a state parties to the World Heritage Convention, Government of Malaysia have the responsibility to take appropriate legal, scientific, technical, administrative and financial measures to protect the heritage as being mentioned in Basic Text 1972 (UWHC, 2005). Since that, conservation of heritage buildings become a main agenda especially in tourism industry whilst in practice, it become a great demand (Harun, 2011).This may promise the bright prospect of the heritage conservation and the professionals' need to have knowledge in this particular area (Azhari \& Mohamed, 2012). Therefore quantity-surveying profession is not excluded from this issue. Quantity surveyor plays a great role as a conservation specialist in producing estimate, preparing tender document, evaluation of contractor, preparing payment and etc. Therefore, they have to enhance knowledge in heritage conservation especially in heritage conservation works.

\subsection{Quantity Surveyors Scope of Basic Services}

To large extent, the scope of construction work will be the same for both new building and conservation work (Lee \& Lim, 2010). Referring to the Memorandum of Agreement issued by the Board of Surveyors Malaysia the basic service provided by quantity surveyor in building conservation works is similar with new works. The basic services are; preparing preliminary estimates and cost plans, preparing bills of quantities and other tender documents, preparing tender reports and contract documents, valuing works in progress for interim valuations including measurement of variations and preparing final accounts (Surveyors, 2004). In preparing tenders for building conservation projects, therefore the quantity surveyor must carefully consider the specificity of non-standard items and demarcate the scope of unique conservation work (Lee \& Lim, 2010). The nature of conservation works is difficult to predict in terms of capacity, extent, specification and risky. Due to the need in providing quantity surveying basic services therefore, a competent quantity surveyor in the area of heritage conservation become more crucial.

\section{RESEARCH METHODOLOGY}

The scope of this research is involving quantity surveying firms that have experienced in building conservation works. Questionnaire survey is the main research methodology applied to achieve the research objectives. It was done in two stages. The first stage was to identify quantity-surveying firms that have experienced in building conservation project by using fixed choice questionnaire. Questionnaires were sent to three hundred thirty-seven (337) quantity-surveying firms registered with the Board of Surveyors Malaysia. They are required to reply YES for a firm that has experience in building conservation works and NO for inexperience firms. About two hundred ninety-seven (297) firms replied the questionnaire, six (6) firms did not reply and thirty-four (34) firms were not active. Out of two hundred ninety-seven (297) firms who reply only forty-six (46) firms have experienced in building conservation project. The second stage involved with the distribution of final questionnaire survey form to the experienced firms in building conservation project. Forty-nine (49) sets of questionnaires were distributed to targeted respondents in Malaysia by post and via the Internet. The respondents were asked the features of heritage building and competency of quantity surveyors in building conservation project. The respondents were instructed to complete the questionnaire based on their experience in handling building conservation project. Data obtained from the returned questionnaire was sorted out and were analysed using Statistical Package for the Social Science (SPSS) software version 20.0 and Partial Least Squares (PLS) version 2.0. Selected appropriate statistical tests were employed using the software, based on the types of data and approach of hypothesis testing. The descriptive statistical test was used for the data presentation and analysis. Partial 
Least Squares Structural Equation Modelling (PLS-SEM) is used to develop theories in this present study. Ultimately, conclusions were drawn up to summarize the data gained from questionnaire survey and literature review.

\section{ANALYSES AND DISCUSSION}

Forty-nine (49) questionnaire surveys were distributed and the rate of response was $74 \%$. There are thirty-six 36) returned questionnaire survey form. The respondents have to evaluate by giving answer in a form of scale from 1 (very strongly disagree) to 7 (very strongly agree). Educating conservation practitioners requires a clear career structure, where the necessary ingredients are merged, involving concepts and theory, scientific methodologies and field practices (Embaby, 2014). Therefore, questions related to theoretical knowledge, skills, practical experiences, interdisciplinary knowledge and multidisciplinary collaboration in building conservation project were asked to all respondents.

Table 1: Features of Heritage Building

\begin{tabular}{|l|c|c|c|c|}
\hline \multicolumn{1}{|c|}{ Features of Heritage Building } & Mean & Std Deviation & Mode & Ranking \\
\hline $\begin{array}{l}\text { FHB 3 - The building has been listed as National } \\
\text { Heritage or Heritage Site. }\end{array}$ & 5.53 & 1.444 & 6 & 1 \\
\hline $\begin{array}{l}\text { FHB 1 - The architectural features of the building } \\
\text { were very special. }\end{array}$ & 5.39 & 1.103 & 5 & 2 \\
\hline $\begin{array}{l}\text { FHB 4 - The building has Outstanding Universal } \\
\text { Value. }\end{array}$ & 5.33 & 1.474 & 5 & 3 \\
\hline $\begin{array}{l}\text { FHB 2 - The construction method of the heritage } \\
\text { building was difference. }\end{array}$ & 5.28 & 1.386 & 6 & 4 \\
\hline
\end{tabular}

Table 1 shows result on mean, standard deviation, mode and ranking of the features of the heritage building. It can be seen that all variables obtained the highest mode of 5 and 6 . Based on the highest mean scores 'The building has been listed as National Heritage or Heritage Site' have 5.53 mean scores and this followed by 'The architectural features of the building were very special' which is 5.39, 'The building has Outstanding Universal Value' achieved 5.33 mean scores and the 'The construction method of the heritage building was difference' have 5.28 mean scores. This result is parallel with the definitions of heritage in Basic text 1972 (UNESCO, 2005), the definition of cultural significance in Burra Charter (Charter \& Significance, 2013) and the definitions of monuments, building \& structures in Hoi An Protocols defined this category encompasses individual built heritage resources and architectural complexes in their setting which are deemed to possess heritage significance and have been or will be listed or declared for protection and conservation. (Engelhardt, 2005).

Table 2: Quantity Surveyor's Competency in Heritage Building Conservation Projects

\begin{tabular}{|l|c|c|c|c|}
\hline \multicolumn{1}{|c|}{$\begin{array}{c}\text { Quantity Surveyor's Competency in Building } \\
\text { Conservation Project }\end{array}$} & Mean & Std. Deviation & Mode & Ranking \\
\hline $\begin{array}{l}\text { QSC 9 - Ability to decide in decision making } \\
\text { process. }\end{array}$ & 5.36 & 0.99 & 6 & 1 \\
\hline QSC 8 - Ability to exchange of ideas & 5.25 & 0.91 & 5 & 2 \\
\hline $\begin{array}{l}\text { QSC 7 - Ability to collaborate well with } \\
\text { multidisciplinary consultants. }\end{array}$ & 5.11 & 1.26 & 6 & 3 \\
\hline QSC 1 - Interdisciplinary skills & 5.11 & 1.17 & 5 & 4 \\
\hline QSC 2 - Theoretical knowledge & 4.97 & 0.97 & 5 & 5 \\
\hline QSC 5 - Ability to work in multidisciplinary groups. & 4.89 & 0.79 & 5 & 6 \\
\hline $\begin{array}{l}\text { QSC 6 - Ability to communicate well with other } \\
\text { professionals }\end{array}$ & 4.89 & 0.92 & 5 & 7 \\
\hline QSC 3 - Building conservation skills & 4.81 & 0.98 & 5 & 8 \\
\hline QSC 4 - Practical experiences & 4.50 & 0.85 & 4 & 9 \\
\hline $\begin{array}{l}\text { QSC 10 - Continuous training in building } \\
\text { conservation works }\end{array}$ & 4.11 & 1.62 & 4 & 10 \\
\hline
\end{tabular}


Table 2 explains result on the quantity surveyor's competency in heritage building conservation projects. Variables that obtained the highest mode (mode $=6$ ) include 'ability to decide in decision making process' and 'ability to collaborated well with multidisciplinary consultants'. However, based on mean scores value, the top three highest scores are 'ability to decide in decision making process', 'ability to exchange ideas' and 'ability to collaborated well with multidisciplinary consultants'. The lowest mean score is 'continuous training in building conservation works. The results confirmed findings from Ali, Rahmat, \& Hassan, (2008), who highlighted about the ability to decide in decision making process will have an implications to cost, quality, time and resource allocation of the conservation projects. They further added that a good decision-making requires informative formulation, clear evaluation and quick reformulation of alternatives. Without adequate and correct data, it is impossible for the conservation professionals to have good decisions in conservation projects. This is parallel with Hoi An Protocols where it clearly states that decision regarding the type and extent of intervention carried out in conservation works should only be taken after extensive research, expert discussion and weighing of conservation options (Engelhardt, 2005).

The ability to exchange ideas ranked second in the analysis; Interaction is required into integrate knowledge of different types and from separate sources, contextualize the available information and sustain learning over time (Jacobson et al., 2011).

In the third rank is the 'ability to collaborate well with multidisciplinary consultants'. Findings by (Orbaşli \& Whitbourn, 2002), confirmed that conservation is a multi-disciplinary process. Suntikul \& Jachna (2013), further added that, different stakeholders bring different perspectives, knowledge and expertise to the conservation process. They further added that the heritage development can be grounded in a more holistic understanding of its potential effects and constraints, opportunities and threats, and multivalent base of knowledge and experience. Conservation of historic buildings and sites involve a wide range of professions from architects, surveyors, engineers, building surveyors, archaeologists, historians, town planners, landscape architects, as well as management professionals, etc. Each of these professional not only makes a contribution to the field of conservation, but also incorporates some features into the knowledge base of their own professional bodies.

Interdisciplinary approach should be adopted in terms of both structure of thought and educational program (Yurtsever \& Cakir, 2012). The nature of conservation works required the quantity surveyor to incorporate interdisciplinary thinking in addressing the needs in conservation works. This leads to establishing relationships with different fields and gaining wide thinking ability in addressing problems or issues in the conservation project (Smith, Gomez-Heras, \& McCabe, 2008). They further added that interdisciplinary approach is the requirement for communication between disciplines, recognition of the possible collaborations that stem from the integration of different strategies and knowledge bases, an appreciation of where other disciplines are coming from and a willingness to learn and borrow from others.

Next in the ranked is theoretical knowledge. The results supported argument by (Harun, 2011; Jones \& Yarrow, 2013; Orbaşli \& Whitbourn, 2002) who emphasized on the importance of theoretical knowledge in building conservation works where the area of works is wide ranging and complex. Professionals are expected to be knowledgeable and this includes quantity surveyors. Theoretical knowledge on heritage conservation will assist the quantity surveyor to understand the scope and sequence of works involved in building conservation works in order for them to write a proper description in the bills of quantities. This knowledge will help them in writing a precise and specific specification and preambles for building conservation. Besides that, it will also assist in pricing and controlling the cost of building conservation works.

Ability to communicate well with other professionals is ranked no. 7. It has been recognized that good conservation are based on correct and adequate information (Lourenço, Peña, \& Amado, 2010). He further added often there is no communication between suppliers and users of heritage documentation. This lack of communication means that records might be prepared with purposes much different from the purpose required by end users.

As one of the heritage professionals, numerous skills are required especially in the 
construction and design. They should be able to think creatively and find solution to the problem. This result supported statement by (Buyukmihci \& Yucel, 2012) who in the opinion that numerous skills are required in conservation works especially in construction and design. Problems may arise if the quantity surveyor did not understands the construction process and did not foresees the hidden work in conservation works (Lee \& Lim, 2010). Numerous skills will assist them in delivering the basic services, especially in doing measurement, preparing estimates, preparing bills of quantities, writing a specification and description. These findings does support findings by Jones \& Yarrow, (2013) and Orbaşli \& Whitbourn (2002) that practical experiences is needed to support the theoretical knowledge. This effort will reduce negligence, incompetency and become best-qualified professionals to undertake such works. They will be equipped with an essential knowledge in understanding the heritage conservation works particularly heritage buildings.

Even continuous training in building conservation is the last in the ranking. This variable is also important, as there is a shortage of local experts in building conservation fields.

Therefore, an urgent need for training is required at institutions of higher education. The teaching staff dealing with heritage management and conservation training at universities around the globe should cooperate with practitioners in the field in developing heritage management training concepts. Burra Charter and Hoi An Protocols emphasize the need of training in conservation.

Partial Least Square path-modelling version 3.0 was used to analyse relationship between Features of Heritage Buildings and Quantity Surveyors Competency. Assessment on the reflective measurement models includes composite reliability to evaluate internal consistency, individual indicator reliability and average variance extracted (AVE) to evaluate the convergent validity. In addition, the Fornell-Larcker criterion and cross loadings are used to assess discriminant validity (Hair, J.F., Sarstedt, M., Hopkins, L., Kuppelwieser, 2014).

Table 3: Cut Off Criteria of the PLS-SEM on Reflective Measurement Models

\begin{tabular}{|l|l|l|}
\hline \multicolumn{1}{|c|}{ Measurement } & \multicolumn{1}{c|}{ Cut Off } & \multicolumn{1}{c|}{ Sources } \\
\hline $\begin{array}{l}\text { Internal Consistency Reliability } \\
\text { (Cronbach's Alpha) }\end{array}$ & $>0.60$ & $\begin{array}{l}\text { (Nunally, J.C., \& Bernstein, } \\
\text { 1978); Hair et al. (2014) }\end{array}$ \\
\hline $\begin{array}{l}\text { Internal Consistency Reliability } \\
\text { (Composite Reliability) })\end{array}$ & $>0.60$ & (Chin, 1998); Hair et al. (2014) \\
\hline $\begin{array}{l}\text { Convergent Validity (Outer) } \\
\text { Loading }\end{array}$ & $>0.70$ & Hair et. al (2014) \\
\hline Indicator Reliability & $>0.40$ but <0.70 & \\
\hline $\begin{array}{l}\text { Average Variance Extracted } \\
\text { (AVE) }\end{array}$ & $>0.40$ & (Hulland, 1999) \\
\hline
\end{tabular}

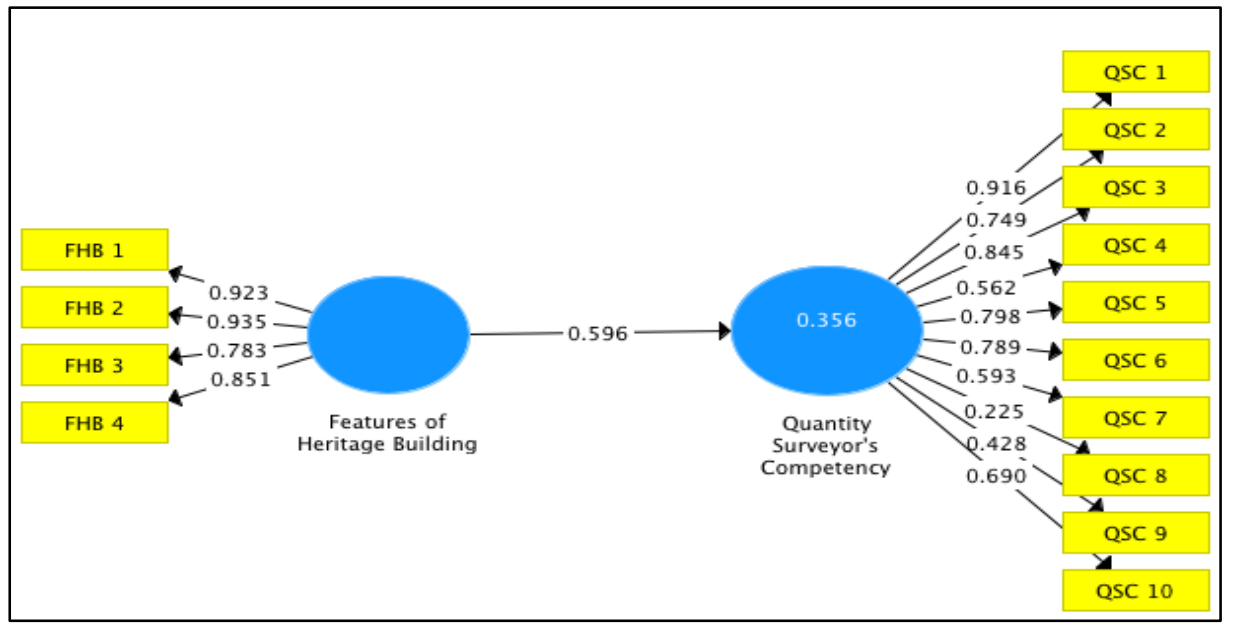

Figure 1: Path Coefficient between Features of Heritage Buildings \& Quantity Surveyors' Competency 
Figure 1 explains result on analysis done on the outer loading for the reflective measurement model. All indicators under Features of Heritage Building (FHB 1, FHB 2, FHB 3 and FHB 4) have a very high reliability (outer loading more than 0.70). Whereas indicators for Quantity Surveyors' Competency show that indicator QSC 8 (outer loading: 0.225 ) should be eliminated from the scale because the convergent reliability is below 0.40. QSC 4, QSC 7, QSC 9 and QSC 10 have convergent reliability between 0.40 and 0.70 which have been accepted for this paper since this research is an exploratory research. . QSC 1, QSC 2, QSC3, QSC 5 and QSC 6 have convergent reliability more than 0.70 .

Table 4: Analysis on Reflective Measurement Models (Before and After Removing Indicator QSC 8)

\begin{tabular}{|l|c|c|c|c|c|c|}
\hline \multirow{2}{*}{ Construct } & \multicolumn{2}{|c|}{ AVE } & \multicolumn{2}{c|}{$\begin{array}{c}\text { Composite } \\
\text { Reliability }\end{array}$} & \multicolumn{2}{c|}{$\begin{array}{c}\text { Cronbach's } \\
\text { Alpha }\end{array}$} \\
\cline { 2 - 7 } & Before & After & Before & After & Before & After \\
\hline Features of Heritage Buildings & 0.766 & 0.766 & 0.929 & 0.929 & 0.897 & 0.897 \\
\hline Quantity Surveyors' Competency & 0.475 & 0.528 & 0.8923 & 0.907 & 0.885 & 0.891 \\
\hline
\end{tabular}

Table 4 shows result on the average variance extracted (AVE), composite reliability and cronbach's alpha. Composite reliability and cronbach's alpha result show that it is above 0.60. It demonstrates that all reflective constructs have high levels of internal consistency reliability. On the convergent validity assessment, result shows that the AVE values of reflective constructs are well above the required minimum level of 0.50 after deletion of one indicator (QSC 8). Thus, the measures of all reflective constructs have high levels of convergent validity.

Table 5: Analysis on Farnell-Larcker Criterion

\begin{tabular}{|l|c|c|}
\hline & $\begin{array}{c}\text { Features of Heritage } \\
\text { Buildings }\end{array}$ & $\begin{array}{c}\text { Quantity Surveyors' } \\
\text { Competency }\end{array}$ \\
\hline Features of Heritage Buildings & $\mathbf{0 . 8 3 0 6}$ & $\mathbf{0 . 6 5 9 5}$ \\
\hline Quantity Surveyors' Competency & 0.6245 & \\
\hline
\end{tabular}

Table 5 shows result on the Fornell-Larcker criterion. According to the Fornell-Larcker criterion, the square root of the AVE of each construct should be higher than the construct's highest correlation with any other construct in the model (Hair et al., 2014). Overall the square roots of the AVEs for the reflective constructs are all higher than the correlations of these constructs with other construct in the path model.

Table 6: Analysis on Cross Loadings

\begin{tabular}{|l|c|c|}
\hline \multicolumn{1}{|c|}{ Indicators } & Features of Heritage Buildings & Quantity Surveyors' Competency \\
\hline FHB 1 & 0.92361 & 0.46079 \\
\hline FHB 2 & 0.93541 & 0.56098 \\
\hline FHB 3 & 0.78311 & 0.40878 \\
\hline FHB 4 & 0.84986 & 0.57198 \\
\hline QSC 1 & 0.66760 & 0.91494 \\
\hline QSC 2 & 0.30239 & 0.75036 \\
\hline QSC 3 & 0.50901 & 0.83491 \\
\hline QSC 4 & 0.29549 & 0.56425 \\
\hline QSC 5 & 0.55114 & 0.79527 \\
\hline QSC 6 & 0.33925 & 0.80165 \\
\hline QSC 7 & 0.16374 & 0.61529 \\
\hline QSC 9 & -0.04128 & 0.44130 \\
\hline QSC 10 & 0.25210 & 0.69874 \\
\hline
\end{tabular}


Table 6 explains analyses on the cross loadings of the reflective measurement model. Discriminant validity is established when an indicator's loading on a construct is higher than all of its cross loadings with other constructs. In this present study all the indicator's loading on a construct is higher than all of its cross loadings with other constructs. All model evaluation criteria have been met, providing support for the measures reliability and validity.

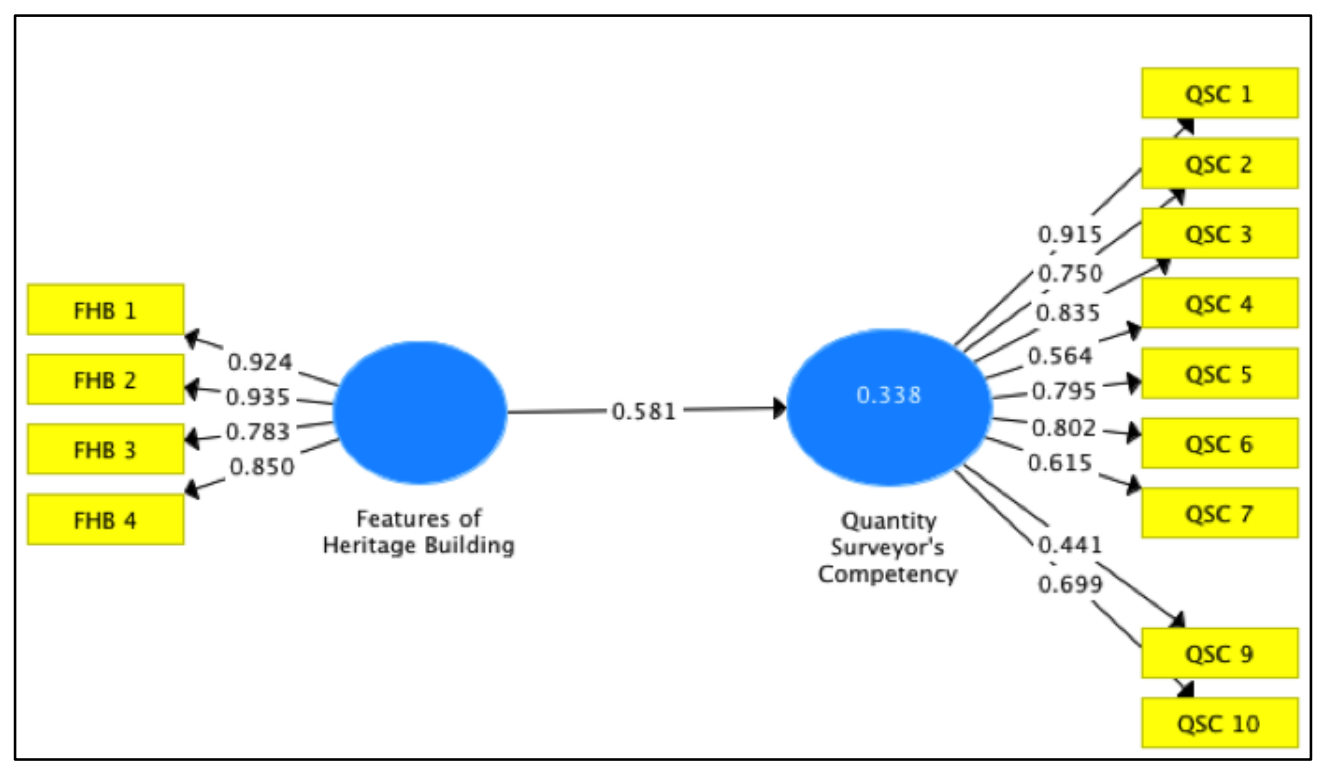

Figure 2: Path Coefficient between Features of Heritage Buildings \& Quantity Surveyors Competencies (after removing indicator QSC 8)

Figure 2 shows the outcome of PLS-SEM Algorithm after it was re-calculated. The coefficient of determination, $\mathrm{R}^{2}$, is 0.338 for the Quantity Surveyor's competency. This present study shows that features of heritage buildings substantially explain $33.80 \%$ of the variance in quantity surveyor's competency. The inner model shows that a feature of heritage building has 0.581 effects on Quantity Surveyor's Competency in Heritage Building Conservation Project. The present study shows that the path relationship between features of heritage buildings and quantity surveyor's competency has a strong positive relationship and it is statistically significant.

\section{CONCLUSION}

The nature of the heritage building and the requirement given by the international and national regulatory bodies has made the heritage conservation management and administration in Malaysia become more important and crucial. Well-meaning attempts are made to preserve the heritage of the region but these cannot succeed without adequate background on the technical knowledge and professional training on the conservation works. The outstanding value requirement and the nature of conservation works have made scope of quantity surveyors' basic services more challenging and difficult. Professional especially the quantity surveyor needs to have a special knowledge and skills in heritage conservation. In delivery their main basic services as a quantity-surveying consultant of the conservation project, knowledge of the building condition, material, technology and histories need to be known. A combination of theoretical and practical knowledge in conservation will enhance the knowledge and skills of quantity surveying, especially in the measurement, estimating, economic and construction technology for building conservation works. This will enhance the knowledge base, especially in building conservation works for the quantity surveyors and will assist them in delivering effective and efficient basic services in this field.

\section{REFERENCES}

Ali, A. S., Rahmat, I., \& Hassan, H. (2008). Involvement of key design participants in refurbishment design process. Facilities, 26(9/10), 389-400. http://doi.org/10.1108/02632770810885742

Azhari, N. F. N., \& Mohamed, E. (2012). Public Perception: Heritage Building 
Conservation in Kuala Lumpur. Procedia Social and Behavioral Sciences, 50(July), 271-279.

http://doi.org/10.1016/j.sbspro.2012.08.033

Beckman, P., \& Bowles, R. (2004). Structural Aspects of Building Conservation. (2nd Editio). Elsevier Butterworth-heinemann.

Buyukmihci, G., \& Yucel, S. (2012). Discussion on Conservation Education through Restoration Praxis in Turkey. Procedia - Social and Behavioral Sciences, 46 , 2721-2727. http://doi.org/10.1016/j.sbspro.2012.05.554

Charter, I., \& Significance, C. (2013). The Australia ICOMOS Charter for Places of Cultural Significance 2013.

Chin, W. (1998). Commentary: Issues and Opinion on Structural Equation Modeling Stable URL : http://www.jstor.org/stable/249674 Issues and Opinion on Structural Equation Modeling, 22(1).

Dada, J., \& Jagboro, G. (2012). Core skills requirement and competencies expected of quantity surveyors: perspectives from quantity surveyors, allied professionals and clients in Nigeria. Australasian Journal of Construction .... Retrieved from http://epress.lib.uts.edu.au/journals/index.p hp/AJCEB/article/view/2808

Drury, P. (2011). Conservation: An Evolving Concept. In J. Taylor (Ed.), The Building Conservation Directory 2012 (19th ed., pp. 6-8). Cathderal Communications Limited.

Engelhardt, R. A. (2005). Hoi An Protocols for Best Conservation Practice in Asia. Assembly.

Hair, J.F., Sarstedt, M., Hopkins, L., Kuppelwieser, V. G. (2014). Partial least squares structural equation modeling ( PLS-SEM ) An emerging tool in business research. http://doi.org/10.1108/EBR-102013-0128

Harun. (2011). Heritage building conservation in Malaysia: Experience and challenges. Procedia Engineering, 20, 41-53. http://doi.org/10.1016/j.proeng.2011.11.13 7

Hegazy, S. M. (2014). Conservation of historical buildings - The Omani-French museum as a case study. HBRC Journal. http://doi.org/10.1016/j.hbrcj.2014.03.010

Hulland, J. (1999). Use of Partial Least Square (PLS) in Strategic Management Research: A Review of Four Recent Studies. Strategic Management Journal, 20, 195204.

Idrus, A., Khamidi, F., \& Sodangi, M. (2010). Maintenance management framework for conservation of heritage buildings in Malaysia. Modern Applied Science, 4(11), 66-77. Retrieved from http://ccsenet.org/journal/index.php/mas/art icle/view/8040

Jacobson, C., Carter, R. W., Hockings, M., \& Kelman, J. (2011). Maximizing conservation evaluation utilization. Evaluation, $\quad$ 17(1), 53-71. http://doi.org/10.1177/1356389010389903

Jones, S., \& Yarrow, T. (2013). Crafting authenticity: An ethnography of conservation practice. Journal of Material Culture, 18(1), 3-26. http://doi.org/10.1177/1359183512474383

Kamal, K. S., Wahab, L. A., \& Ahmad, G. (2008). Pilot survey on the conservation of historical buildings in malaysia, (Icbedc), 104-115.

Lee, Q., \& Lim, Y. (2010). Preparation of tender for building conservation workcurrent practices in Malaysia. International Journal of Human and Social Sciences, 5(3), $6 . \quad$ Retrieved from https://waset.org/journals/waset/v29/v29182.pdf

Letellier, R. (2007). Recording , Documentation and Information Management for the Conservation of Heritage Places: Guiding principles. (E. Escobar, Ed.). The Getty Conservation Institute.

Lourenço, P. B., Peña, F., \& Amado, M. (2010). A Document Management System for the Conservation of Cultural Heritage Buildings. International Journal of Architectural Heritage, 5(1), 101-121. http://doi.org/10.1080/15583050903318382

Mansfield, J., \& Reyers, J. (2000). Conservation Refurbishment Projects: A Comparative Assessment of Risk Management Approach. The Cutting EdgeThe Real Estate Research Conference of the RICS Research Foundation.

Mohamed, B., Ahmad, a G., \& Ismail, I. (2002). Heritage route along ethnic lines: the case of Penang. Historic Environment, 16(2), 18-22.

Nur Farhana Azmi, Faizah Ahmad, Azlan Shah Ali (2015), Heritage Place Inventory: Tools for establishing the significance of places, Journal of Design and Built Environment, Vol.15(1), pp.15-23.

Nkado, R., \& Meyer, T. (2001). Competencies of professional quantity surveyors: a South African perspective. Construction Management and Economics, 19(5), 481491.

http://doi.org/10.1080/01446190110044852 
Nunally, J.C., \& Bernstein, I. (1978). Psychometric Theory. New York: McGraw-Hill.

Orbaşli, A., \& Whitbourn, P. (2002). Professional Training and Specialization in Conservation: An ICOMOS Viewpoint. Journal of Architectural Conservation, 8(3), 61-72. http://doi.org/10.1080/13556207.2002.1078 5327

PMI (2002) Project Manager Competency Development Framework, Pennsylvania, Newton Square: Project Management Institute.

Pye, E., \& Sully, D. (2007). The Conservator. The Conservator, 30(1), 19-37.

Rahmat, I., Nordin, H., \& Ali, A. S. (2005). The complexity and performance of housing refurbishment projects / Ismail Rahmat, Hashimah Nordin and Azlan Shah Ali. Built Environment Journal. Retrieved from

http://eprints.uitm.edu.my/6492/1/BEJ 2 $\% 282 \% 29 \% 2 \mathrm{C} \mathrm{37-48 \% 2C} \mathrm{2005.pdf}$

Reyers, J., \& Mansfield, J. (2001). The assessment of risk in conservation refurbishment projects. Structural Survey, 19(5), 238-244. http://doi.org/10.1108/02630800110412480

Said, S. Y., Akshah, H., \& Ismail, E. D. (2013). Heritage Conservation and Regeneration of Historic Areas in Malaysia. Procedia - Social and Behavioral Sciences, 105, 418-428. http://doi.org/10.1016/j.sbspro.2013.11.044

Siti Nor Fatimah Zuraidi, Zainal Abidin Akasah, M. A. A. R. (2011). Masalah dalam Pemuliharaan Bangunan Warisan di Malaysia. Persidangan Kebangsaan Sains Sosial Unimas 2011: Pembangunan Ke Arah Masa Depan Yang Mapan, (April), 112.

Smith, B. J., Gomez-Heras, M., \& McCabe, S. (2008). Understanding the decay of stonebuilt cultural heritage. Progress in Physical Geography, 32(4), 439-461. http://doi.org/10.1177/0309133308098119

Stenning, A., \& Evan, G. (2007). Costing and Contracts for Historics Buildings. In Understanding Historic Building Conservation.

Suntikul, W., \& Jachna, T. (2013). Contestation and negotiation of heritage conservation in Luang Prabang, Laos. Tourism Management, 38, 57-68. http://doi.org/10.1016/j.tourman.2013.02.0 05

Surveyors, B. of. (2004). Consultancy Services Contract in Malaysia.

UHC (2005). Basic Text of the 1972 World Heritage Convention. United Nation Educational Scientific and Cultural Organization, France.

UNESCO. (2005). Basic Texts of the 1972 World Heritage Convention. United Nation Educational.

Yurtsever, B., \& Cakir, G. (2012). An Assessment for Interdisciplinary Education Modal Implementation of Basic Design Education in Architecture. Procedia Social and Behavioral Sciences, 51, 157161.

http://doi.org/10.1016/j.sbspro.2012.08.137 